\title{
Literary Memories, Historical Amnesia
}

\author{
Marija Gjorgjieva Dimova \\ University “Ss. Cyril and Methodius”, Skopje, Republic of Macedonia
}

\begin{abstract}
The basic interest of this text is certain aspects in the relation between literature, history, and memory. Particullary, this relation has been examined through the prism of subverting the traditionally established distinction between history and literature, in which certain types of memory have its own contribution. The main focus, for that purpose, is based on the concepts of postmemory, secondary memory, apocryphal history, creative anachronism and figures of memory, and their applicative capacities concerning particular theme fields which express common interest both for history and literature.
\end{abstract}

Keywords: literature, history, memory

There is probably a rule according to which one remembers or forgets, but since the narratives of memory are most often history or fiction, we avoid thinking of such rules ... There is no literature without memory, without past and without nostalgia: if you forget easily, you will never write anything.

-Miljenko Jergović

A History Reader (2006)

\section{Introduction}

The literature-history-memory triad, among other things, has challenged the traditional distinction existing between literature and history, by embracing certain types of memory identified in historical and literary contexts, respectively. The complementarity of this triad was founded on which has been corroborated on two levels: Firstly, literature and history stand as two discursive practices whose relation, in the past few decades, has been subjected to multiple redefinitions that, among other things, were founded on the emphasis on shared mnemonic aspects; secondly, literature and history are identified as two discourses of/about the past, namely, as two modes of remembering, thus of reshaping historical reality. Through the scope of this relation literature is perceived as supplementing history —its empty, blank spaces, its "dark areas"-by fictionalisation, revision, and reinterpretation. Hence, several theoretical categories come to the forefront as useful interpretive tools, i.e., illustrative of the transgression present between literature and history and the shared mnemonic aspects.

In a historiographic context, the relation between history and memory has been elaborated and argued many times over. ${ }^{1}$ Within the research of testimony as one of the crucial sources of history, Dominick LaCapra

Marija Gjorgjieva Dimova, Ph.D., Associate Professor, Department of General and Comparative Literature, Faculty of Philology "Blaze Koneski"—Skopje, University "Ss. Cyril and Methodius".

1 See Dominick LaCapra (1998), History and Memory after Auschwitz; J. le Goff (1992), History and Memory. 
established the distinction between primary and secondary memory: Primary memory is "that of a person who has lived through events and remembers them in a certain manner", whereas secondary is "the result of critical work on primary memory whether by the person who initially had the relevant experiences or, more typically, by an analyst, observer or secondary witness as the historian" (LaCapra, 1998, pp. 20-21). Thus, in relation to trauma, memory is always secondary: What happened has not been integrated in experience or remembered directly, so the event is reconstructed based on its effects. Literature also has the capacity to utilise the traumatic event as a model and thus transform its testimony in a literary context. The mnemonic aspects of literature have been underscored in various theories of intertextuality, which in turn assign it great mnemonic power. In that sense, intertextuality is viewed as the memory of a text: Through intertextuality, the memory space is inscribed into the text, just as the text is inscribed into the memory space, placing itself between the texts. On that note, the intertextually-marked text gets inscribed into the textual memory of culture, while at the same time reorganising it, thus creating its own mnemonic space that is implied by its intertextuality. Hence, the literary text is a visible mode that demonstrates the mnemonic processes in literature, which are seen as a "mnemonic art par excellence" since it "supplies the memory for a culture and records such a memory" (Lachmann, 2002, p. 209), since literature itself is an act of memory. Consequently, the relation between literature and history, through the scope of shared their mnemonic aspects, bears several implications:

(1) Contemporary historiographical and literary theories, referring to their own practices, advocate the thesis of a textually-mediated approach to the past;

(2) The intertextual foundation of the historical/literary text implies a discourse of the past that is an act of interpretation, of the intertexts from/on the past;

(3) The textually-mediated approach to the past includes the discursive and narrative dimensions, too. If the return to the past is discursively and narratively realised, then the approach is not only based on events (i.e., their reconstruction), but on the narrative reshaping of the past as well, thus verifying that a narrative is one of the most powerful symbolic memory spaces (Kulavkova, 2009, p. 44). Hayden White, when viewing history and literature as competitive narrations of/about the past, concludes that narrative representations do not consist of mere factual statements and arguments; but rather, of poetic and rhetorical elements that help transform the list of facts into a narrative (White, 2003, pp. 35-37);

(4) The historical/literary approaches to the past are founded on principles of selection, construction, and interpretation: They zoom in on a certain segment, thus implying a given version (viewpoint) constructed through interpretive processes;

(5) Historians and authors, in their discursive/narrative shaping of selected events, offer their own representations, linguistically-mediated and formed. Thus, historical/literary representations of the past are carried out in accordance with certain conventions - those of language, representation, and medium;

(6) Historical/literary representations of the past are motivated by the need to make sense of the past, that is, to place it in certain frameworks of meaning, and to relate it to a certain history. It practically helps define the priority position of the present as a cognitively retroactive position, from which historians/authors approach the past. The distance between the past and the present thus allows for the recontextualisation of the past as a process of filling in the distance with interpretive constructs. 


\section{Postmemory: The Imaginative Projections of the Second Generation}

In the common interest of literature and history in the traumatic past, ${ }^{2}$ its representations are further corroborated by the parallel existing between two theoretical concepts: secondary memory (in historiography) and postmemory (in literature/art). Postmemory describes

the relationship of children of survivors of cultural or collective trauma to the experiences of their parents, experiences that they "remember" only as the stories and images with which they grew up, but that are so powerful, so monumental, as to constitute memories in their own right. (Hirsch, 1999, p. 8)

This structure of transgenerational or intergenerational transfer of traumatic experience, and its knowledge, is marked by "its temporal and qualitative difference from survivor memory, its secondary or second-generation quality memory, its basis in displacement, its belatedness" (Hirsch, 1999, p. 8). One of the defining aspects of postmemory reflects its mediated, textual nature - its reliance on images, narratives, and documents transferred from one generation to another. In fact, in the analyses conducted by LaCapra on works of literature and film, as in Hirsch's analysis of family photographs, there is an emphasis on "the complicated set of relations among traumatic event memory and imagination" (LaCapra, 1998, p. 180), that is to say, the processes of recreation, projection, and imaginative investment which postmemory's relation to the past is founded on (Hirsch, 1999). In the literary works of members of the second generation/s there is an obvious displacement from the documentary/testimonial position (typical for first-generation members), so that their works create new dimensions, mainly towards interpreting the past from a distance - through the scope of a knowledge they previously did not possess. Along those lines, Danilo Kiš' novel Psalm 44 (1962) might be read in the vein of postmemory: "[a]nd that novel, Psalm 44, is based on my own experience, as well as the testimonies of those rare relatives that returned from the camps" (Kiš, 2007, p. 152). But Kiš offers a broader postmemory framework, namely by taking a journalist's report as the prototext of the novel and thus transcending the strictly familial postmemory track. One of the common denominators of secondary memory and postmemory examines their mediatory dimension. According to Hirsch, the scholarly and academic works of descendants further confirm that even the most intimate family knowledge of the past is mediated by widely accessible public images and narratives. Along these lines, LaCapra too concludes that any attempt to represent events that have not been experienced boils down to presenting experiences mediated by memory, so that those born later are "exposed to the Holocaust only through mediated or secondary memory and largely through the media of popular culture" (LaCapra, 1998, p. 173). In Kiš' case, the mediatory aspects of representing the past have been provided by multiple mediations: Apart from testimonials of surviving family members and the model (the journalist's report), the mediation of the broader socio-political and literary context of Post-WWII Yugoslavia is also brought to the forefront:

I believe that the existence of a certain latent resistance to the Jewish subject in the Yugoslav reality has helped me in the search of what I have named my own literary metaphor. (...) I mean: I hid my Jewish element in my literary works since I feared both the weight of the facts that are dangerous to literature and the possibility I might become or be declared a minority author. (Kiš, 2007, pp. 152-153)

\footnotetext{
${ }^{2}$ In the context of Balkan literatures, these are the traumatic experiences of the Aegean exodus, of Goli Otok, and of the armed conflicts on the territory of former Socialist Yugoslavia.
} 
Indeed, the processes of projection, imaginative investment, and creation, marking the mediated and interpretive nature of postmemory, are present in Psalm 44 as well. ${ }^{3}$ If, in the absence of personal experience, imagination structures the relationship between postmemory and history, then the processes of fictionalisation are a way of "filling the gaps" of postmemory. The re-creative aspects of narrative postmemory in the novel are evident on a structural level: The underscored associativity, the fragmented narrative, the multi-focalisation, the analeptic interruptions, are the dominant processes confirming that postmemory does not consist merely of events, but also of their representations and interpretations, conventionally and contextually conditioned. The motivation behind these processes is explained by the author himself, particularly in relation to the figure of the (absent) father:

Hence there is a need to complete his character, to bridge the gaps between his two appearances. This process is, in fact, similar to the one I use when developing characters for which there are documentary details, certain insufficient biographical facts, and between two facts there is a gaping hole that needs to be filled with the solid matter of imagination, which, according to the strength of verisimilitude, will have the force of a document. (Kiš, 2007, pp. 15-16)

\section{Apocryphal History: The Revenge of Memory}

Apocryphal history is a particularly popular process of re-interpretive supplementation of historiography, usually accomplished in two ways (McHale, 2001): by supplementing historical records so as to restore what has been overlooked, suppressed, or forgotten, thus operating in the so-called "dark areas" of history, or by displacing official history, mostly accomplished by violating the constraints of the "dark areas" of history. Both forms mediate in establishing a parallel between the officially accepted version of history, and the other, different, fictionalised version. Apocryphal histories (as postmemory) exhibit "the imaginative manoeuvres of interpretation post festum" (Wesseling, 1991, p. 168), while also revealing the subjective deformations of history in epistemological categories.

The novel-esque reinterpretation focusing on the "dark areas" of history is further illustrated in Slobodan Мицковиќ's novel Alexander and Death (1992): The novel zooms in on an event that has remained insufficiently familiar in historiography - the death of Alexander the Great and his funeral. Whereas historical archives undeniably verify the existence of the great conqueror, mainly through the scope of his military endeavours, they remain silent on the aspects which the novel is founded on: his death and subsequent funeral. Мицковиќ, utilising this vacuum in the historiographical records, gets rid of the presence of the emperor himself: Only the memory of him and the desire to trace the final days of his life, as well as his fate following his death, are present. The apocryphal history in the novel, through which the various relations with the "dark areas" of history, that is to say, with the historiographic texts, are established, might also be interpreted as a revisionist placement of existing textualisations of the historical referent in a new (novel-esque) context: By intimating the existence of a different version of history the reliability of the officially established versions of historiography is challenged. Hence, the apocryphal relativisation of these versions interferes with the relationship between history and literature as well.

\footnotetext{
3 "That is my only biography, the only world I know. (...) Its disappearance, its distance in time is what makes it literarily appealing. (...) I believe that in my books the Jewish problem is not an intellectual school, but the single real content of my life, which is literary. (...) It is a history of a nearly fantastical realism since it is a matter of real things that at the same time do not exist, are gone. That makes them be in a sort of a mist of the unreal, and yet not disappear into the fantastical” (Kiš, 1997, p. 179).
} 


\section{Creative Anachronism: The Interplay Between Past and Present}

Literature oftentimes resorts to an intentional use of anachronisms in various forms, a process Brian McHale refers to as "creative anachronism" (2001, pp. 93-94). This process is illustrated in Мицковиќ's novel:

And from this man I first heard the word that will follow me even after death and will not leave me in peace. I shall remain whole, unrotten in this cell in which I wished to be left after death and have the entrance covered. (...) He called him, he called him Alexander the Great. (Мицковиќ, 1992, p. 326)

The narrator imparts the information that Alexander gets the epithet "the Great" 50 years after his death. ${ }^{4}$ This, however, is an "innocent" anachronism, since it remains on the level of the narrator's discourse: It does not enter the fictional world of the novel, thus underscoring the temporal distance between the act of narration and the narrated events. This process further emphasises the tense and re-interpretive relation between past and present, which in the novel is articulated as a relation between the past witnessed or written about, and the present in which writing or memory takes place. The anachronistic tensions between past and present are also expressed by Miljenko Jergović in his A History Reader (2006). The title itself is indicative, in regards to the implication of the transgressiveness between literature and history, and the underscoring of their shared mnemonic aspects, corroborated by the prologue as expounded by the author himself: "A History Reader is neither history, nor fiction, but a catalogue of that which exists as an inventory of a subjective history of the city, the country and the times" (Jergović, 2006, p. 9). Even though the title is reminiscent of that of a textbook, Jergović offers autobiographical narratives of the past: the personal, the familial, and the collective combined. The anachronisms shaping the narrative constructs of the past help making sense of it through narrativisation and interpretation: "This book does not cover actual events, but their memory and the strategy of forgetting. In it there are falsely remembered names and dates; the cities have become other cities" (Jergović, 2006, p. 9). If the narrativisation of reality means imposing upon it the form of a story (White, 1992, p. 2), then Jergović's narratives utilise the creative anachronism as a transformation of the past through the formal requirements of the narrative, namely, as a mode of transferring knowledge (of the past) to narration (about the past). That stresses the distance between past and present, event, and the narrative of the event, thus prioritising the second member of the relation. Consequently, the common narrative dimensions of history and literature are underscored as well.

\section{The Figures of Memory Topos}

The figures of memory referring to metanational and civilisational values and identities (Kulavkova, 2009, p. 43 ), i.e., the figures of memory arising from the interplay between notions and experiences (Assman, 2005, p. $44)^{5}$ have proven to be a particularly exploited topos in literature, doubly indicative:

(1) In an intertextual sense, this topos is an intersection between history and literature illustrating the manners of their textual interconnections;

(2) In an interpretive sense, the numerous recontextualisations of the figures of memory witness their

\footnotetext{
${ }_{5}^{4}$ As opposed to the fact that it occurred nearly two centuries after his death.

5 Assman refers to the theory of social construction of memory of Maurice Halbwachs, who believes that each person and historical fact in memory is transposed in a certain concept or symbol, and thus purportively shaped. Halbwachs speaks of "images of memory", whereas Assman prefers the phrase "figures of memory" since the notion of figure, as opposed to the notion of image, does not refer just to the iconic, but also to the narrative shaping (Assmann, 2005, p. 44).
} 
transformation, as well as their ambivalence: They are interpreted as specifics of individual cultures/ethnoi; also, as a synonym of intercultural dialogue (Kulavkova, 2009, p. 48).

The figures of memory topos also call attention to the mnemonic aspects of history and literature: They transgress the boundaries between literature and history, pointing to the common fixation on certain historical figures and their textualisations and interpretations, i.e., the modes of literary and historical memory. In Михајловски's My Skanderbeg (2006), the reinterpretive levels are indicated para-citationally —in the title and the subhead. The cursive script of the possessive determiner in the title (my title) intimates the reception of the text as a contribution to the textual complex of this historical figure. Along these lines, the subhead is also indicative, namely, revealingМихајловски's revisionist tendency: Thirteen Contemporary Narrative Assaults on This Overexploited Subject from the Viewpoint of an Unbiased Macedonian Hand with a Select Bibliography and Conclusion. That is to say, the author has recontextualised this topos in a contemporary (narrative) context, venturing to offer another version of this figure of memory, or "contribute to shedding light on the 'dark' areas of his history and culture" (Михајловски, 2006, p. 145), whereby transcending the strictly ethnocentric aspects of considering Skanderbeg. In a broader sense, Михајловски revives precisely the mnemonic, intertextual and transcontextual aspect of the figures of memory:

Skanderbeg is as great as Shakespeare. Just as you can throw Shakespeare among Romantics, Realists, Symbolists, Modernists, Postmodernists and he fits everywhere, so you can throw Skanderbeg only among Orthodox Christians, or only among Muslims, or Catholics, or Albanians, or Macedonians, Serbs, Vlachs, Greeks, and he will fit everywhere, but nowhere will he be complete. Because he is everyone and above everyone. (Михајловски, 2006, p. 312)

The particular (inter) textualisation of the figures of memory topos is not merely a memory of a previous textual concretisation, but also a memory of existing interpretations. My Skanderbeg substantiates this very dimension. In accordance with semiotic conceptions of memory and culture, history and culture are seen as two semiotic systems, the functions of which consist not merely of a transmission of existing information (texts), but of creating new information (texts) as well. "History is oftentimes referred to as the memory of humanity. The past makes for the contents of memory; yet without memory, thinking here and now is impossible. It is the deep foundation of the current process of cognition" (Лотман, 2006, p. 302).

\section{Conclusion}

Current historical and literary representations of the past (the historical events and figures) — concretised by means of the concepts and processes that were the subject of my interest (postmemory, secondary memory, apocryphal history, creative anachronism and fugures of memory) - emphasise the inversive, interpretative, and re-interpretative interplay between past and present, between literature and history, and between fact and fiction.

\section{References}

Assmann, J. (2005). Kulturno pamčenje (Cultural memory). Zenica: Vrijeme.

Gross, M. (2006). O historiografiji poslednjih trideset godina (About the historiography of the last thirty years). Godišnjak Filozofskog fakulteta Sveučilišta u Zagrebu, 2, 583-609.

Hirsch, M. (1999). Projected memory: Holocaust photographs in personal and public fantasy. In M. Bal, J. Crew, and L. Spitzer (Eds.), Acts of memory (pp. 3-23). Hanover/London: University Press of New England.

Hirsch, M. (2001). Surviving image: Holocaust photographs and the work of postmemory. The Yale Journal of Criticism, 14(1), $5-37$. 
Hirsch, M. (2004). Introduction. In M. Hirsch and I. Kacandes (Eds.), Teaching the representation of the holocaust (pp. 1-33). New York: The Modern Language Association of America.

Jergović, M. (2006). Historijska čitanka (A history reader). Zagreb: V.B.Z.

Kiš, D. (1997). Gorki talog iskustva (Bitter residue of experience). M. Miočinović, (Ed.). Split: Feral Tribune.

Kiš, D. (2007). Život, literatura (Life, literature). M. Miočinović, (Ed.). Beograd: Prosveta.

Kulavkova, K. (2009). From a Black God to a Black Arab: Different mythical and historical actualizations of the universal matrix of Black. In K. Kulavkova (Ed.), Interpretations: The Black Arab as a figure of memory (No. 3, pp. 21-46). Skopje: Macedonian Academy of Science and Arts.

LaCapra, D. (1998). History and memory after Auschwitz. Ithaca and London: Cornell University Press.

Lachmann, R. (2002). Phantasia, memoria, rhetorica. Zagreb: Matica hrvatska.

McHale, B. (2001). Postmodernist fiction. London and New York: Routledge.

Tolić Oraić, D. (1990). Teorija citatnosti (The theory of citation). Zagreb: GZH.

Wesseling, E. (1991). Writing history as a prophet: Postmodernist innovations of the historical novel. Amsterdam and Philadelphia: John Benjamins Publishing Company.

White, H. (1990). The content of the form: Narrative discourse and historical representation. Baltimore and London: The Johns Hopkins University Press.

White, H. (2003). Fabulacija povijesti i problem istine u reprezentaciji povijesti (Historical emplotment and the problem of truth in historical representation). $K$., 1, 33-54.

Киш, Д. (1983). Псалм 44. (Psalm 44). Загреб/Београд: Глобус/Просвета.

Лотман, J. (2006). Семиосфера (On the semiosphere). Скопје:Три.

Михајловски, Д. (2006). Мојот Скендербеј (My Skanderbeg). Скопје: Каприкорнус.

Мицковиќ, С. (1992). Александар и смртта (Alexander and death). Скопје: Култура. 